\title{
Homogenization Treatment Parameter Optimization and Microstructural Evolution of Al-Cu-Li Alloy
}

\author{
Yang Shengli ${ }^{1,2}, \quad$ Shen Jian ${ }^{1,2}, \quad$ Yan Xiaodong ${ }^{2}, \quad$ Li Xiwu ${ }^{1}, \quad$ Zhang Fei $^{2}, \quad$ Sun Baoqing ${ }^{2}$ \\ ${ }^{1}$ State Key Laboratory of Nonferrous Metals and Processes, General Research Institute for Nonferrous Metals, Beijing 100088, China; \\ ${ }^{2}$ Nonferrous Metals Processing Division, General Research Institute for Nonferrous Metals, Beijing 100088, China
}

\begin{abstract}
The microstructure evolution and composition distribution of the industrially cast $\mathrm{Al}-\mathrm{Cu}-\mathrm{Li}$ alloy during single-step and tow-step homogenization were investigated by optical microscopy (OM), scanning electron microscopy (SEM), energy dispersive spectrometry (EDS), X-ray diffraction (XRD) and differential scanning calorimetry (DSC). The results show that severe dendrite segregation exists in the $\mathrm{Al}-\mathrm{Cu}-\mathrm{Li}$ as-cast alloy. $\mathrm{Cu}$ distributes unevenly from the grain boundary to inside. But the changes of $\mathrm{Mg}$, $\mathrm{Zn}, \mathrm{Mn}$ and $\mathrm{Ag}$ are not obvious. At the grain boundary, there are a large amount of coarse nonequilibrium eutectic phases $\mathrm{Al}_{2} \mathrm{Cu}$, $\mathrm{Al}_{2} \mathrm{Cu}$ containing a trace of $\mathrm{Mg}$ and $\mathrm{Al}_{2} \mathrm{CuMg}$ phase. After the optimized two-step homogenization treatment, most of the nonequilibrium eutectic phase and second phase $\left(\mathrm{Al}_{2} \mathrm{CuMg}\right.$ and $\left.\mathrm{Al}_{2} \mathrm{CuLi}\right)$ dissolve into $\alpha(\mathrm{Al})$ matrix. A small amount of Fe-rich and $\mathrm{Mn}$-rich phase are still distributed at the grain boundaries. $\mathrm{Al}_{2} \mathrm{CuMg}$ phase melting point is lower than that of $\mathrm{Al}_{2} \mathrm{Cu}$ phase. $\mathrm{Al}_{2} \mathrm{CuMg}$ and $\mathrm{Al}_{2} \mathrm{Cu}$ phase gradually dissolve into the matrix at 495 and $515{ }^{\circ} \mathrm{C}$, respectively. The suitable homogenization treatment for the Al-Cu-Li alloy is $495{ }^{\circ} \mathrm{C} / 24 \mathrm{~h}+515{ }^{\circ} \mathrm{C} / 24 \mathrm{~h}$. The results of homogenization can be described by homogenization kinetic analysis, which agrees well with experimental observation.
\end{abstract}

Key words: Al-Cu-Li alloy; homogenization treatment; nonequilibrium eutectic phases; kinetic analysis

Metal material of high performance is still the most important metallic material for the structure in the aerospace industry ${ }^{[1]}$. Al-Li alloys are widely used in aviation and aerospace industries because of their low density, high elastic modulus, small anisotropy and excellent resistivity to damage ${ }^{[2-5]}$. In comparison to the traditional $2 \mathrm{xxx}$ and $7 \mathrm{xxx}$ series $\mathrm{Al}$ alloys, $\mathrm{Al}-\mathrm{Li}$ alloys have higher modulus (15\% 25\%) and higher specific strength $(8 \% \sim 15 \%)$, with provide aeronautical designers an opportunity to significantly reduce the weight of aeronautical and space structures for ensuring enhanced fuel efficiencies and higher payloads. Al-Li alloys has been successfully applied to the floor of A380 and the fuselage section of C919 aircraft.

In the present paper, the composition of the $\mathrm{Al}-\mathrm{Cu}-\mathrm{Li}$ alloy is consistent with that of the third-generation $\mathrm{Al}-\mathrm{Li}$ alloy, which reduces the content of lithium, and increases the content of copper. However, in order to improve the properties of the alloy, a variety of microalloying elements should be added. Silver and magnesium were added as nucleating agents for $\mathrm{T} 1$ phase on the work of Polmear. Zirconium and manganese were added for grain structure control to refine the grain structure in the weld zone. D. Tsivoulas et al ${ }^{[6]}$ studied the interaction between zirconium and manganese dispersoid-forming elements on their combined addition in $\mathrm{Al}-\mathrm{Cu}-\mathrm{Li}$ alloys. The role of added manganese is similar to that of zirconium, mainly forming $\mathrm{Al}_{6} \mathrm{Mn}$ and $\mathrm{Al}_{20} \mathrm{Cu}_{2} \mathrm{Mn}_{3}$ dispersed particles in an effort to control the recrystallization of the alloy ${ }^{[7]}$. In addition, $\mathrm{Al}_{6} \mathrm{Mn}$ and $\mathrm{Al}_{20} \mathrm{Cu}_{2} \mathrm{Mn}_{3}$ dispersed particles can disperse the coplanar slip and reduce the anisotropy of the alloy ${ }^{[8]}$.

Interdendritic segregation during direct chill semicontinuous casting is a considerable amount of non-equilibrium eutectics because of the complexity and the high content of elements of the alloys ${ }^{[9]}$. Studies showed that the interdendritic segregation seriously deteriorates the properties of the alloys ${ }^{[10-13]}$. The result of homogenization greatly influence the thermal 
Table 1 Chemical composition of the Al-Cu-Li alloy (wt\%)

\begin{tabular}{ccccccccccccc}
\hline $\mathrm{Cu}$ & $\mathrm{Li}$ & $\mathrm{Mg}$ & $\mathrm{Mn}$ & $\mathrm{Zn}$ & $\mathrm{Zr}$ & $\mathrm{Ag}$ & $\mathrm{Fe}$ & $\mathrm{Si}$ & $\mathrm{Ti}$ & $\mathrm{Al}$ \\
\hline 3.52 & 1.28 & 0.38 & 0.29 & 0.36 & 0.12 & 0.37 & 0.03 & 0.02 & 0.024 & $\mathrm{Bal}$. \\
\hline
\end{tabular}

processing, microstructures and mechanical properties of Al-Li alloy ${ }^{[14]}$. Despite detailed studies of homogenizing treatments in various kinds of aluminum alloy, less attention was focused on the Al-Li alloy with high in $\mathrm{Cu}$ content. The aim of the present study is to investigate the features of the microstructure evolution during homogenization with the help of OM, SEM, EDS, DSC and XRD analysis. Homogenization kinetic analysis derived binding experiments. And the best homogenization treatment of $\mathrm{Al}-\mathrm{Cu}-\mathrm{Li}$ alloys was achieved.

\section{Experiment}

The experimental material was provided by Southwest Aluminum (Group) Co. Ltd. The chemical composition of the $\mathrm{Al}-\mathrm{Cu}-\mathrm{Li}$ alloy examined in this investigation is shown in Table 1. The cast ingots homogenization conditions were as follows. The first one was a single-step homogenization treatment. The samples were homogenized at 485, 495, 500, 515 and $525^{\circ} \mathrm{C}$ for $24 \mathrm{~h}$. The second one was a two-step homogenization treatment. The samples was homogenized at $495^{\circ} \mathrm{C}$ for $24 \mathrm{~h}$ followed by $515^{\circ} \mathrm{C}$ for $6,12,18,24,30$, and $36 \mathrm{~h}$. Differential scanning calorimetry (DSC) analyses were conducted using a SDT-Q600 differential scanning calorimeter at a constant heating rate of $10^{\circ} \mathrm{C} / \mathrm{min}$ from $25^{\circ} \mathrm{C}$ to $600^{\circ} \mathrm{C}$, and the standard sample was $\mathrm{Al}_{2} \mathrm{O}_{3}$. The microstructure characteristics of as-cast and homogenized samples were analyzed by optical microscopy (OM). The samples were etched with Keller reagent ( $1 \mathrm{~mL} \mathrm{HF}, 1.5 \mathrm{~mL}$ HCL, $2.5 \mathrm{~mL}$ $\mathrm{HNO}_{3}$ and $95 \mathrm{~mL} \mathrm{H}_{2} \mathrm{O}$ ). The area and line scanning examination were conducted on an energy dispersive spectrometry (EDS) measurement attached to a scanning electron microscopy (SEM). For SEM examination, the samples were polished but kept unetched. X-ray diffraction (XRD) was employed identify the alloy phases present in the as-cast and the homogenized alloy.

\section{Results and Discussion}

\subsection{Characterization of as-cast microstructure}

High cooling rates and non-equilibrium solidification conditions of the direct chill (DC) casting result in the formation of nonequilibrium eutectics and intermetallics ${ }^{[14]}$. Optical micrographs and SEM images of the as-cast alloy are shown in Fig.1. The alloy consists of typical as-cast eutectic structure, exhibiting severe dendritic segregation (Fig.1a). A considerable number of coarse continuous nonequilibrium eutectic phases and intermetallics are presented in the interdendritic region and grain boundaries (Fig.1b), which greatly deteriorate the strength and toughness of the alloy and bring some bad influences to the processing property and application ${ }^{[14]}$. There are mainly two kinds of intermetallic phases in as-cast microstructure (Fig.1c). The results of EDS analysis of point A, B in Fig.1c and point C in Fig.1d are listed in Table 2. The qualitative and quantified analyses of point $\mathrm{A}$ and $\mathrm{B}$ indicate that the chemical composition of grey intermetallic phase (Fig.1c, point A) is $\mathrm{Al}_{2} \mathrm{CuMg}$, and the bright phase is $\mathrm{Al}_{2} \mathrm{Cu}$ (Fig.1c, point $\mathrm{B}$ ) which dissolved a small amount of $\mathrm{Mg}$. Analysis of point $\mathrm{C}$ infers that it is probably a mixture of $\mathrm{Al}_{2} \mathrm{CuMg}, \mathrm{Al}_{2} \mathrm{Cu}, \mathrm{Al}_{3} \mathrm{Zr}, \mathrm{Al}_{6} \mathrm{Mn}$ and some $\mathrm{Zn}$-contained phase. Other regions of the cast structure in a discrete particle show the same characteristics.

Fig.2 is SEM microstructure and the elements mappings of as-cast $\mathrm{Al}-\mathrm{Cu}-\mathrm{Li}$ alloy, which show the distribution of the main elements $(\mathrm{Cu}, \mathrm{Mg}, \mathrm{Zn}, \mathrm{Mn}$ and $\mathrm{Ag})$. $\mathrm{Li}$ is hard to be detected for its light mass. It can be seen that $\mathrm{Cu}$ concentration is larger in grain boundary than inside of grains. Min Jia et al ${ }^{[15]}$ presents that $\mathrm{Mg}$ and $\mathrm{Ag}$ tend to be concentrated together at the ends of these white continuous phases. The element segregation seriously deteriorates the properties of the alloys. Therefore, the homogeneity is necessary to eliminate the segregation of these elements. Microscopic analysis shows that the diffusion is a migration process within the material due to thermal motion of atoms or molecules, which can be described by the

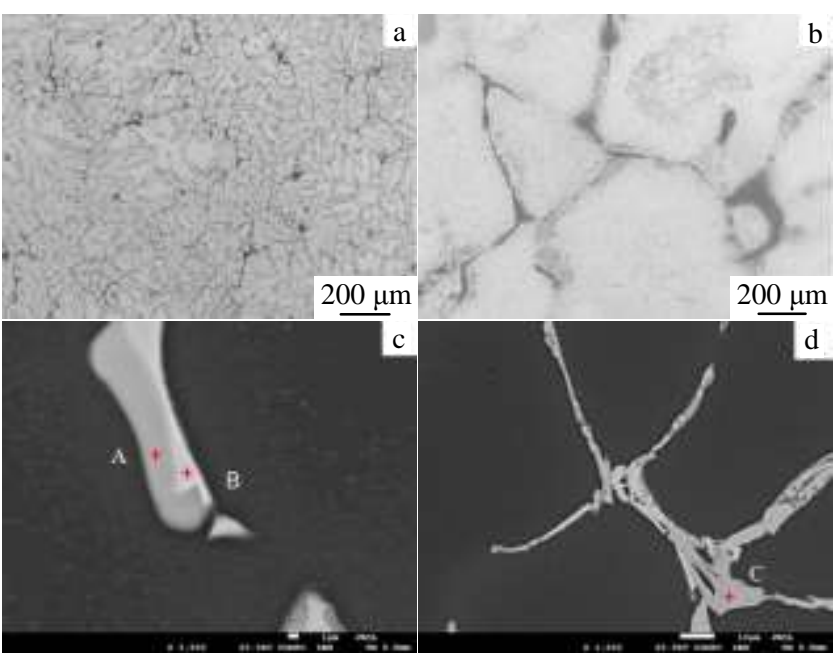

Fig.1 Optical microstructures (a, b) and SEM microstructures (c, d) of the as-cast alloy

Table 2 Chemical composition of intermetallic phases in Fig.1 (at\%)

\begin{tabular}{ccccccc}
\hline Point & $\mathrm{Al}$ & $\mathrm{Cu}$ & $\mathrm{Mg}$ & $\mathrm{Zr}$ & $\mathrm{Mn}$ & $\mathrm{Zn}$ \\
\hline $\mathrm{A}$ & 62.37 & 21.80 & 15.83 & - & - & - \\
$\mathrm{B}$ & 65.89 & 32.45 & 01.66 & - & - & - \\
$\mathrm{C}$ & 71.77 & 16.00 & 02.53 & 01.49 & 07.38 & 00.83 \\
\hline
\end{tabular}



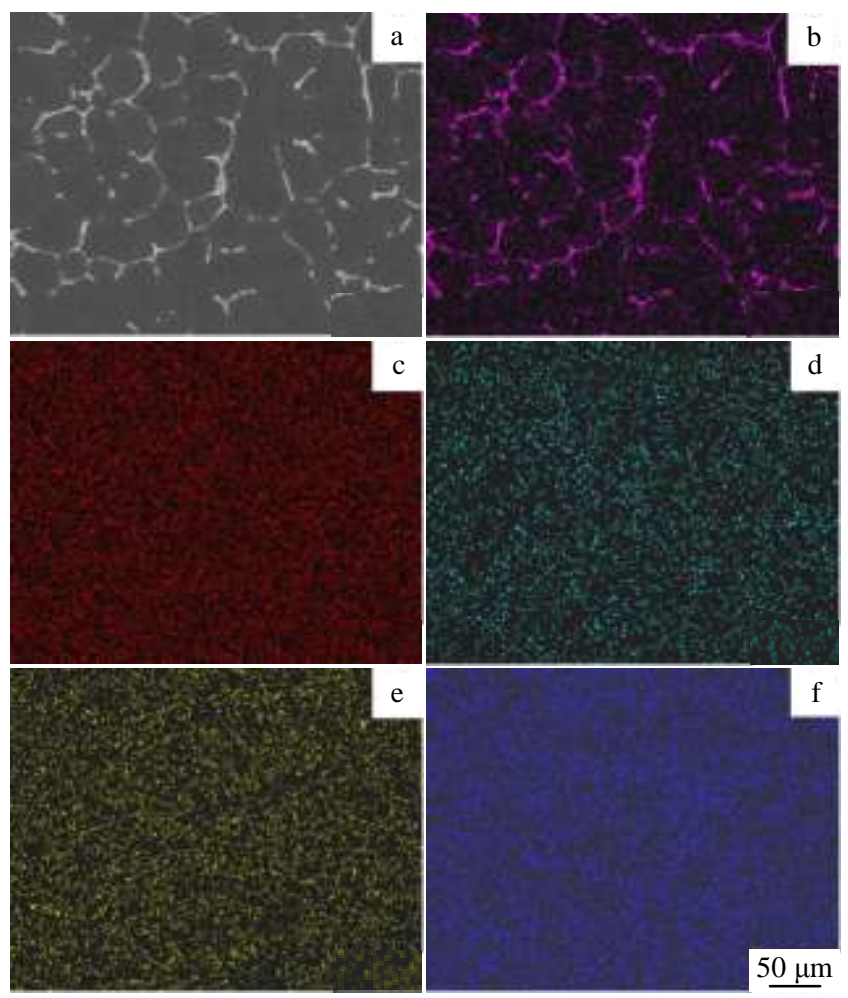

Fig.2 SEM microstructure (a) and main elements distribution in ascast alloy: (b) $\mathrm{Cu}$, (c) $\mathrm{Mg}$, (d) $\mathrm{Zn}$, (e) $\mathrm{Mn}$, and (f) $\mathrm{Ag}$

law of diffusion ${ }^{[16]}$. According to the law of diffusion, the higher the temperature, the more possible the elimination of
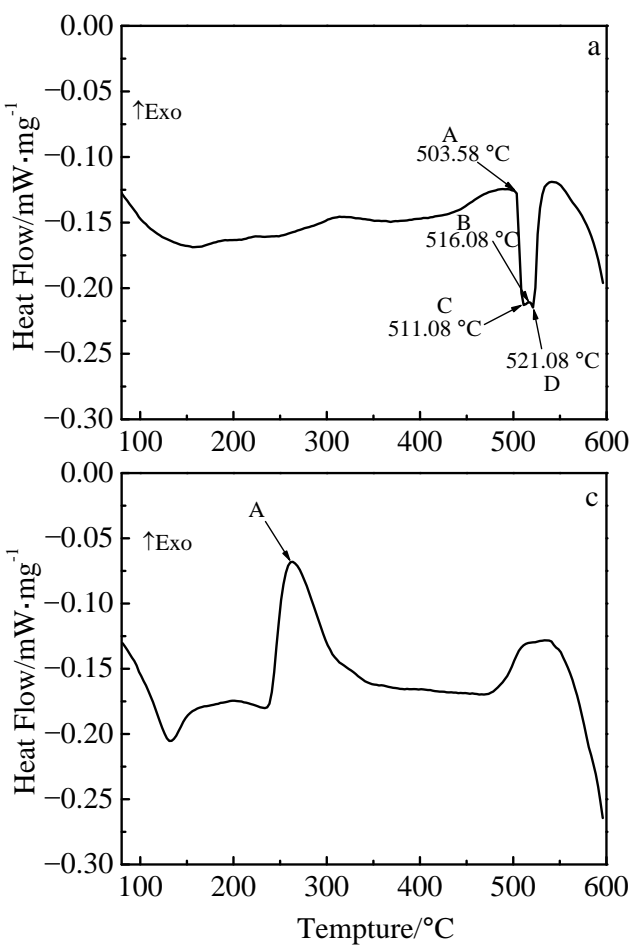

dendritic segregation. But the overheating phenomenon occurs in the microstructure at over higher temperature. Therefore, the optimal parameters of homogeneity should be explored in order to obtain good homogenization effect.

\subsection{DSC analysis of as-cast and homogenized alloy}

DSC curves are illustrated in order to confirm the melting temperature of the secondary phases during the homogenization treatment process, which is useful to guide the homogenization treatment of the alloy, as shown in Fig.3. Fig.3a shows the DSC curve of as-cast $\mathrm{Al}-\mathrm{Cu}-\mathrm{Li}$ alloy. Two endothermic peaks are observed in the as-cast alloy, sited at $511.08^{\circ} \mathrm{C}$ (Fig.3a, C) and $521.08^{\circ} \mathrm{C}$ (Fig.3a, D). The low eutectic phase will be dissolved firstly when the temperature reaches $503.58^{\circ} \mathrm{C}$ (Fig.3a, A) and the other low melting phases is near $516.08^{\circ} \mathrm{C}$ (Fig.3a, B). So the upper limit temperature for homogenization is $503.58^{\circ} \mathrm{C}$. Fig. $3 \mathrm{~b}$ shows the DSC curves of $\mathrm{Al}-\mathrm{Cu}-\mathrm{Li}$ alloy homogenized at $495^{\circ} \mathrm{C}$ for $24 \mathrm{~h}$. The endothermic peak at $511.08^{\circ} \mathrm{C}$ (Fig.3a, C) disappears after homogenization at $495^{\circ} \mathrm{C}$ for $24 \mathrm{~h}$, which may be attributed to the dissolution of some non-equilibrium phases during homogenization. However, the endothermic peak at $526.08{ }^{\circ} \mathrm{C}$ (Fig.3b, B) still exists. So it may be the insolubilization of another higher melting point second phase. The endothermic peaks at $526.08^{\circ} \mathrm{C}$ disappears when the alloy is homogenized at $515^{\circ} \mathrm{C}$ for $24 \mathrm{~h}$ (Fig.3c). Therefore, we infer that the type of the second phase corresponding to the endothermic peak at $526.08{ }^{\circ} \mathrm{C}$ is different from the second phase at $495^{\circ} \mathrm{C}$. This is because the temperature of the second endothermic peak is higher than the former. Two-step homogenization treatment is implemented, in order to avoid

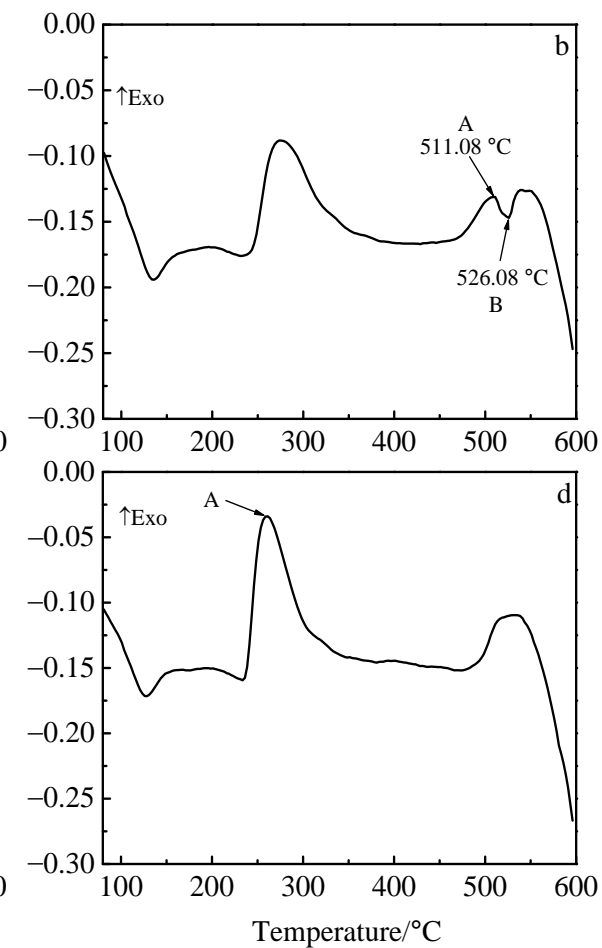

Fig. 3 DSC curves of as-cast (a) and homogenized alloy: (b) $495^{\circ} \mathrm{C} / 24 \mathrm{~h}$, (c) $515^{\circ} \mathrm{C} / 24 \mathrm{~h}$, and (d) $495^{\circ} \mathrm{C} / 24 \mathrm{~h}+515^{\circ} \mathrm{C} / 24 \mathrm{~h}$ 
melting of low-melting point eutectic phase.

Fig.3d shows the DSC curve of Al-Cu-Li alloy homogenized at $495^{\circ} \mathrm{C}$ for $24 \mathrm{~h}$, and then homogenized at $515^{\circ} \mathrm{C}$ for $24 \mathrm{~h}$. Second phase totally dissolves into matrix. Compared with the single-step homogenization, the second endothermic peak is present at different temperatures (Fig.3a, D, 521.08 ${ }^{\circ} \mathrm{C}$ and Fig. $3 b, B, 526.08^{\circ} \mathrm{C}$ ) under different homogenization conditions. It is concluded that the pretreatment has certain effect on the evolution of intermetallic phase ${ }^{[17]}$. After homogenization, an exothermic peak occurs at $250 \sim 300^{\circ} \mathrm{C}$ (Fig.3c, A and Fig.3d, A) because some second phase is precipitated during the air cooling process.

\subsection{Evolution of microstructure during homogenization}

The optical microstructure of homogenized alloy at different temperatures for $24 \mathrm{~h}$ is shown in Fig.4. The result show that the non-equilibrium eutectic phase gradually is dissolved into the matrix with increasing the homogenization temperature from $485^{\circ} \mathrm{C}$ to $525^{\circ} \mathrm{C}$, and the grain boundaries become thinner and clearer. In addition, the distribution of the second phase along the grain boundary becomes discontinuous (Fig.4b). But, some dendrites and second phases still exist. The overheating phenomenon of microstructure is observed when the temperature rises to $515^{\circ} \mathrm{C}$, because of the presence of the melting compounds both in the grain boundaries and triple conjunctions (Fig.4c). And the phenomenon of overheating phenomenon becomes more serious when the temperature is raised to $525^{\circ} \mathrm{C}$ (Fig.4d). Therefore, the first-step homogenization process is designed to $495^{\circ} \mathrm{C}$ for $24 \mathrm{~h}$.

Backscattered electron images of homogenized alloy are shown in Fig.5. The chemical composition of second phases labeled in Fig.5 is shown in Table 3. After homogenization at $495{ }^{\circ} \mathrm{C}$ for $24 \mathrm{~h}$ (Fig.5a), most of low-melting point eutectic phase is eliminated. However, some second phase remains (Fig.5a, point A), whose melting temperature is higher than

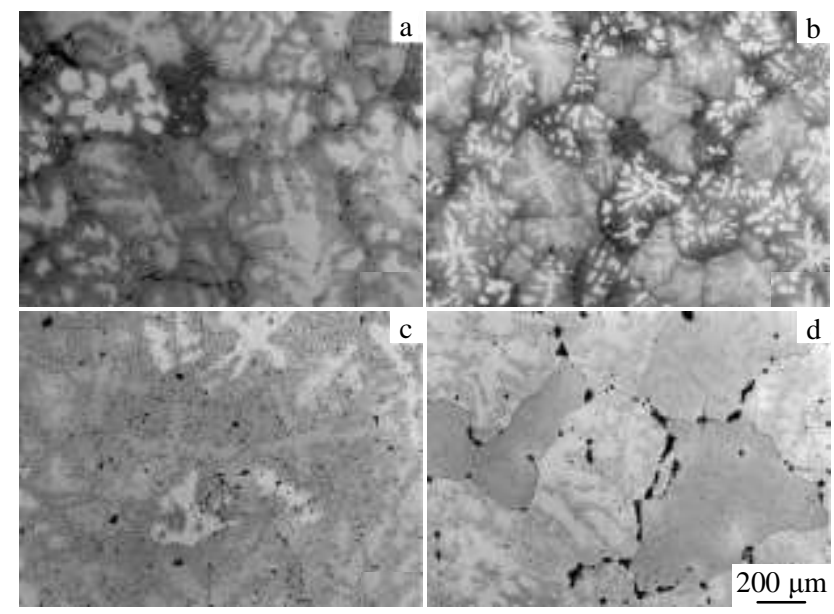

Fig.4 Optical microstructure of specimens homogenized at different temperatures for $24 \mathrm{~h}$ : (a) $485^{\circ} \mathrm{C}$, (b) $495^{\circ} \mathrm{C}$, (c) $515^{\circ} \mathrm{C}$, and (d) $525^{\circ} \mathrm{C}$

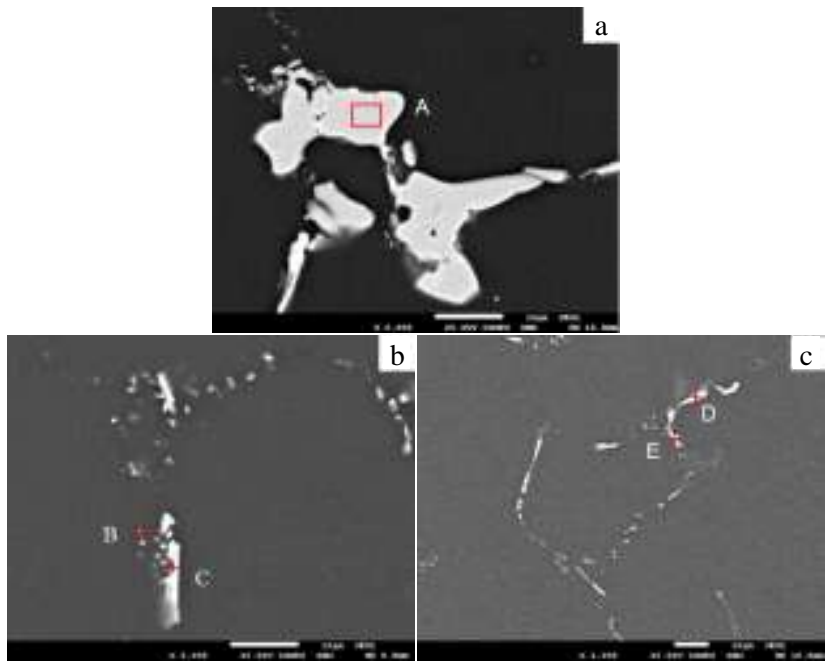

Fig.5 Backscattered electron images of alloy homogenized: (a) $495^{\circ} \mathrm{C} / 24 \mathrm{~h}$, (b) $515^{\circ} \mathrm{C} / 24 \mathrm{~h}$, and (c) $495^{\circ} \mathrm{C} / 24 \mathrm{~h}+515^{\circ} \mathrm{C} / 24$ $\mathrm{h}$

Table 3 Chemical composition of second phases in Fig.5 (at\%)

\begin{tabular}{ccccccc}
\hline Point & $\mathrm{Al}$ & $\mathrm{Cu}$ & $\mathrm{Mg}$ & $\mathrm{Mn}$ & $\mathrm{Fe}$ & $\mathrm{Si}$ \\
\hline $\mathrm{A}$ & 64.23 & 35.77 & - & - & - & - \\
$\mathrm{B}$ & 93.83 & 06.17 & - & - & - & - \\
$\mathrm{C}$ & 80.58 & 13.75 & - & 02.31 & 03.35 & - \\
$\mathrm{D}$ & 86.16 & 07.90 & 00.87 & 02.23 & 02.51 & 00.32 \\
$\mathrm{E}$ & 85.49 & 05.53 & 00.39 & 06.40 & 01.85 & 00.34 \\
\hline
\end{tabular}

$495^{\circ} \mathrm{C}$. According to the EDS analysis of this phase, the ratio of $\mathrm{Al}$ to $\mathrm{Cu}$ is close to 2:1, as indicated in Table 3. It is inferred to be $\mathrm{Al}_{2} \mathrm{Cu}$ phase. Fig. $5 \mathrm{~b}$ shows the alloy homogenized at $515^{\circ} \mathrm{C}$ for $24 \mathrm{~h}$, The EDS analysis reveals that the $\mathrm{Al}_{2} \mathrm{Cu}$ has be dissolved into the matrix. Combined with the analysis of DSC in section 2.2 the conclude that the $\mathrm{Al}_{2} \mathrm{CuMg}$ phase has a lower melting point than the $\mathrm{Al}_{2} \mathrm{Cu}$ phase, because the $\mathrm{Al}_{2} \mathrm{CuMg}$ phase dissolves after homogenization at $495{ }^{\circ} \mathrm{C}$ for $24 \mathrm{~h}$. But the $\mathrm{Al}_{2} \mathrm{Cu}$ phase has not been dissolved until homogenized at $515{ }^{\circ} \mathrm{C}$. Only small residual Fe-rich and Mn-rich phase are distributed at the grain boundaries (Table 3, point $\mathrm{C}$ ). But, with the risk of overheating described above, it is necessary to make two-step homogenization. Fig.5c shows the alloy homogenized at $495^{\circ} \mathrm{C}$ for $24 \mathrm{~h}$ followed by $515^{\circ} \mathrm{C}$ for $24 \mathrm{~h}$. The EDS analysis result shows that almost all the residual second phase are Fe-rich and Mn-rich phase (Table 3, point D \& E), which are insoluble impurity intermetallic compounds. It can't be eliminated by homogenization treatment.

After the first-step homogenization treatment, the melting point of the residual second eutectic comes to $526.08{ }^{\circ} \mathrm{C}$ (Fig.3b). Fig.6 shows the backscattered electron images of the specimens homogenized at $495^{\circ} \mathrm{C}$ for $24 \mathrm{~h}$ followed by a high temperature step $515^{\circ} \mathrm{C}$ for different time. By prolonging the 
holding time, the majority of the second phase decreases in the

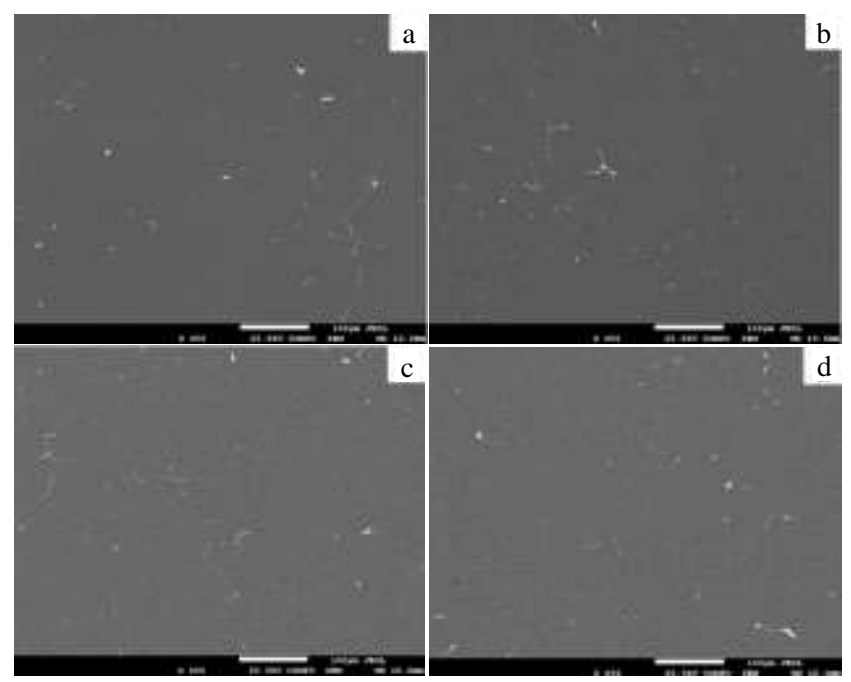

Fig.6 Backscattered electron images of alloy homogenized at $495^{\circ} \mathrm{C} / 24 \mathrm{~h}+515^{\circ} \mathrm{C}$ for different time: (a) $6 \mathrm{~h}$, (b) $12 \mathrm{~h}$, (c) $24 \mathrm{~h}$, and (d) $36 \mathrm{~h}$

volume fraction and the massive residual phases become smaller and sparse. But some coarse phases still exist. When the holding time is further prolonged, there is no obvious dissolution in the second phase (Fig.6d).

\subsection{X-ray diffraction analysis}

$\mathrm{X}$-ray diffraction patterns of the as-cast and the homogenized alloy are shown in Fig.7. The phases of as-cast alloy are consisted mostly of $\mathrm{Al}_{2} \mathrm{CuLi}, \mathrm{Al}_{2} \mathrm{CuMg}$ and $\alpha(\mathrm{Al})$. After homogenization at $495^{\circ} \mathrm{C}$ for $24 \mathrm{~h}, \mathrm{Al}_{2} \mathrm{CuMg}$ and $\mathrm{Al}_{2} \mathrm{CuLi}$ phase decrease. There is no obvious diffraction peak in X-ray diffraction patterns except for $\alpha(\mathrm{Al})$ under the homogenization conditions of $495^{\circ} \mathrm{C}$ for $24 \mathrm{~h}$ followed by $515^{\circ} \mathrm{C}$ for $24 \mathrm{~h}$. Fe-rich and $\mathrm{Mn}$-rich phase can not be detected by X-ray diffraction because of their low contents.

\subsection{Homogenization kinetic analysis}

Nonequilibrium eutectics and intermetallics will gradually disappear visually and dendritic segregation will decrease slowly when the homogenization process is conducted. Fig. 8

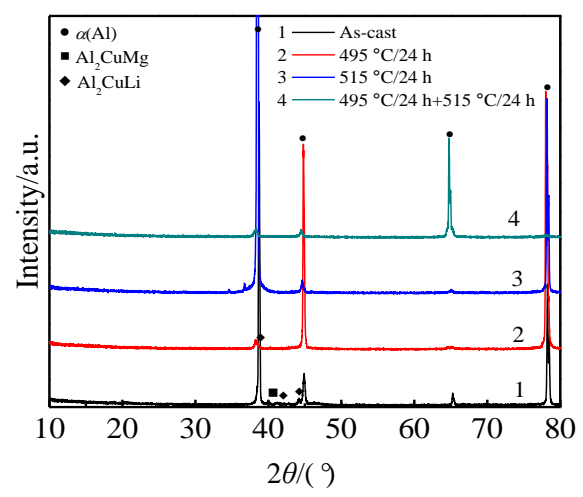

Fig.7 XRD patterns of as-cast and homogenization alloy

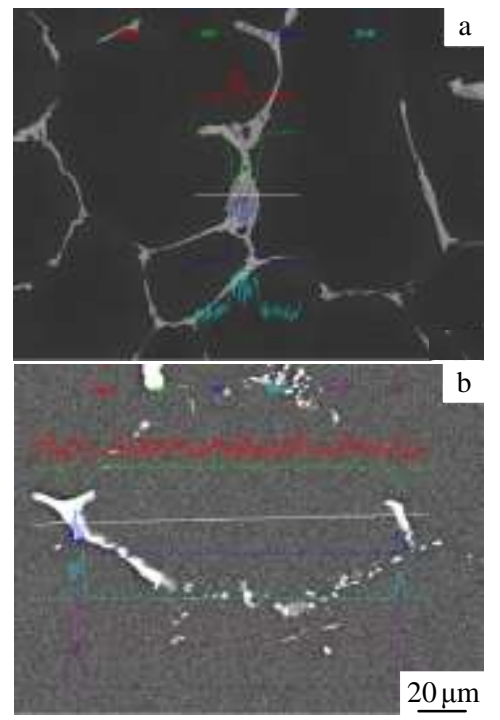

Fig.8 EDS line scanning of as-cast (a) and homogenized alloy at $495^{\circ} \mathrm{C} / 24 \mathrm{~h}+515^{\circ} \mathrm{C} / 24 \mathrm{~h}(\mathrm{~b})$

shows the EDS line scanning analyses of the Al-Cu-Li alloys in the as-cast and the homogenized state at $495{ }^{\circ} \mathrm{C}$ for $24 \mathrm{~h}$ followed by $515^{\circ} \mathrm{C}$ for $24 \mathrm{~h}$. The results show the distribution of the main elements $(\mathrm{Cu}, \mathrm{Mg}, \mathrm{Zn}, \mathrm{Mn})$ within grains and grain boundaries periodically. It is an intuitive and effective method to measure the effect of the homogenization heat treatment by observing the characteristic evolution of grain boundary and dendritic $\operatorname{arm}^{[14]}$. In order to analyze the homogenization process in theory, a homogenization kinetic equation was deduced based on Fick's First Law of diffusion by many investigators. The homogenization kinetic equation is ${ }^{[17,18]}$ :

$$
\frac{1}{T}=A \ln \left(\frac{t}{B L^{2}}\right)
$$

where, $A=R / Q$ and $B=4.6 / 4 \pi^{2} D_{0}$. Here $T, t, Q$, and $L$ is the homogenization temperature, holding time, activation energy of diffusion, and interdendritic spacing and $D_{0}$ is the constant.

Please refer to the documentation process ${ }^{[13,16,19]}$. The homogenization kinetic curves can be got, if the related parameters of as-cast microstructure are given. Table 4 shows the alloying elements diffusion coefficient in $7 \mathrm{xxx} \mathrm{Al}$ alloys at different homogenization temperatures ${ }^{[20]}$. The diffusion coefficients of $\mathrm{Cu}, \mathrm{Mg}$ and $\mathrm{Zn}$ are $3.93 \times 10^{-14}, 9.40 \times 10^{-14}$ and $1.80 \times 10^{-14}$ respectively at $495{ }^{\circ} \mathrm{C}$. The result shows that the diffusion velocity is $\mathrm{Zn}>\mathrm{Mg}>\mathrm{Cu}$. With the increase of temperature to $525^{\circ} \mathrm{C}$, the difference between them is more and more serious. Fei Zhang et al $^{[21]}$ studied the homogenization heat treatment of $2099 \mathrm{Al}-\mathrm{Li}$ alloy. The results show that the main alloying elements diffusion velocity is $\mathrm{Zn}>\mathrm{Mn}>\mathrm{Cu}$, and the homogenization temperature to eliminate the main alloying elements segregation is $\mathrm{Cu}>\mathrm{Mn}>\mathrm{Zn}$. Therefore, all the studied results show that the diffusion velocity is $\mathrm{Zn}>\mathrm{Mn}>\mathrm{Cu}$ 
both in the 7xxx and Al-Li alloys.

Table $4 \mathrm{Cu}, \mathrm{Zn}$ and $\mathrm{Mg}$ atomic diffusion coefficient $\left(\mathrm{m}^{2} / \mathrm{s}\right)$

\begin{tabular}{ccccccc}
\hline Phase & Calculation equation ${ }^{[19]}$ & $485^{\circ} \mathrm{C}$ & $495^{\circ} \mathrm{C}$ & $505^{\circ} \mathrm{C}$ & $515^{\circ} \mathrm{C}$ & $525^{\circ} \mathrm{C}$ \\
\hline $\mathrm{Cu}$ & $D=0.000048 \exp (-16069 / T)$ & $2.98 \times 10^{-14}$ & $3.93 \times 10^{-14}$ & $5.14 \times 10^{-14}$ & $6.68 \times 10^{-14}$ & $8.63 \times 10^{-14}$ \\
$\mathrm{Mg}$ & $D=0.00000623 \exp (-13831 / T)$ & $7.41 \times 10^{-14}$ & $9.40 \times 10^{-14}$ & $1.19 \times 10^{-13}$ & $1.49 \times 10^{-13}$ & $1.85 \times 10^{-13}$ \\
$\mathrm{Zn}$ & $D=0.0000245 \exp (-14385 / T)$ & $1.40 \times 10^{-13}$ & $1.80 \times 10^{-13}$ & $2.29 \times 10^{-13}$ & $2.89 \times 10^{-13}$ & $3.63 \times 10^{-13}$ \\
\hline
\end{tabular}

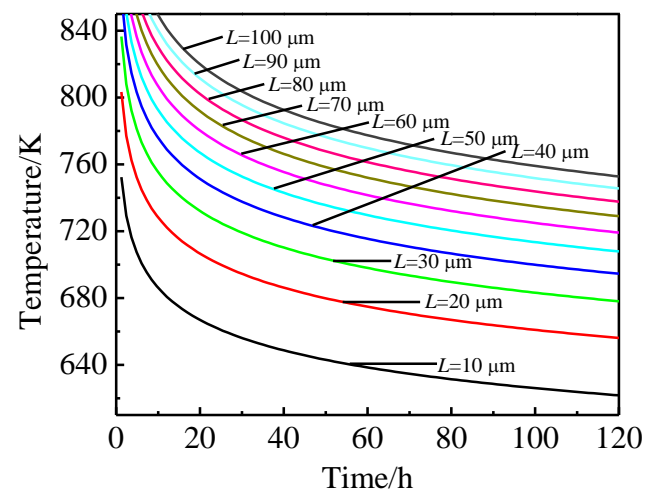

Fig.9 Curves of homogenization alloy kinetics

Combined with the detail in section $2.1, \mathrm{Cu}$ element is of serious segregation in grain boundaries. Therefore, it can be considered that the homogenization process is mainly affected by the diffusion of $\mathrm{Cu}^{[1,22,23]}$. The homogenization kinetic curves of Al-Cu-Li alloy can be obtained by substitution of $D_{0}(\mathrm{Cu})=0.084 \mathrm{~cm}^{2} \cdot \mathrm{s}^{-1}, \quad Q(\mathrm{Cu})=136.8 \mathrm{~kJ} \cdot \mathrm{mol}^{-1}$ and $R=8.31$ $\mathrm{J} /(\mathrm{mol} \cdot \mathrm{K})$ into Eq.(1), as shown in Fig.9.

The average dendrite spacing $(L)$ of the samples as-cast and after the first-step homogenization treatment in this study is $\mathbf{5 6}$ $\mu \mathrm{m}$ and $72 \mu \mathrm{m}$, respectively, obtained from quantitative metallographic analysis. By substituting the average interdendritic spacing $L$ into Eq.(1), the suitable homogenizing parameters are obtained. According to the homogenization kinetic curves as shown in Fig.9, at the optimized temperatures of 495 and $515^{\circ} \mathrm{C}$, the corresponding soaking time are 26.4 and $22.7 \mathrm{~h}$, respectively, which are in good agreement with the experimental results. The results of homogenization kinetic analysis provide a valuable technology reference for the $\mathrm{Al}-\mathrm{Cu}-\mathrm{Li}$ alloy production.

\section{Conclusions}

1) Serious dendritic segregation exists in the as-cast $\mathrm{Al}-\mathrm{Cu}-\mathrm{Li}$ alloy. The main element $\mathrm{Cu}$ is largely enriched in grain boundaries, and its concentration decreases from grain boundary to inside, but the changes of $\mathrm{Mg}, \mathrm{Zn}, \mathrm{Mn}$ and $\mathrm{Ag}$ are not obvious.

2) A large number of coarse nonequilibrium eutectic phases $\mathrm{Al}_{2} \mathrm{Cu}, \mathrm{Al}_{2} \mathrm{Cu}$ dissolve a small amount of $\mathrm{Mg}$ and $\mathrm{Al}_{2} \mathrm{CuMg}$ phase is distributed in the grain boundary. $\mathrm{Al}_{2} \mathrm{CuMg}$ phase melting point is lower than the melting point of $\mathrm{Al}_{2} \mathrm{Cu}$ phase. $\mathrm{Al}_{2} \mathrm{CuMg}$ phase gradually dissolves into the matrix at $495^{\circ} \mathrm{C}$, and $\mathrm{Al}_{2} \mathrm{Cu}$ phase dissolves at $515^{\circ} \mathrm{C}$.
3) The optimized two-step homogenization processing is $495^{\circ} \mathrm{C} / 24 \mathrm{~h}+515^{\circ} \mathrm{C} / 24 \mathrm{~h}$, which is consistent with the results of homogenizing kinetic analysis. After two-step homogenization, most of the nonequilibrium eutectic phase and the second phase $\left(\mathrm{Al}_{2} \mathrm{CuMg}\right.$ and $\left.\mathrm{Al}_{2} \mathrm{CuLi}\right)$ dissolve into $\alpha(\mathrm{Al})$ matrix. Fe-rich and Mn-rich phase can't be dissolved into the matrix during the homogenization.

\section{References}

1 Liu Xiong, Liu Zhiyi, Yu Dier et al. Materials Science and Engineering of Powder Metallurgy[J], 2013, 18(3): 333

2 Rioja R J, Liu J. Metallurgical Materials Transactions A[J], 2012, 43(9): 3325

3 Li Jinfeng, Zheng Ziqiao, Ren Wenda et al. Transactions of Nonferrous Metals Society of China [J], 2006, 16(6): 1268

4 Yoshimura R, Konno T J, Abe E et al. Acta Materialia[J], 2003, 51(14): 4251

5 Li Bo, Pan Qinglin, Yin Zhimin. Materials Science and Engineering A[J], 2014, 614: 199

6 Tsivoulas D, Tobson J D, Sigli C et al. Acta Materialia[J], 2012, 60: 5245

7 Zheng Ziqiao, Li Jinfeng, Chen Zhiguo et al. The Chinese Journal of Nonferrous Metals[J], 2011, 21(10): 2337

8 Csontos A A, Starke Jr E A. Metallurgical and Mater Transactions A[J], 2000, 31(4): 1965

9 Li Niankui, Cui Jianzhong. Transactions of Nonferrous Metals Society of China [J], 2008, 18(6): 769

10 Wu Z W, Chen Y, Meng L. J Alloy Compd[J], 2009; 481(2): 236

11 Wu L M, Wang W H, Hsub Y F et al. J Alloy Compd[J], 2008, 456(1): 163

12 Totik Y, Sadeler R, Kaymaz I et al. Mater Process Tech[J], 2004, 147(1): 60

13 Liu X Y, Pan Q L, Fan X et al. J Alloy Compd[J], 2009; 484(1): 790

14 Wang Haijun, Xu Ju, Kang Yonglin et al. J Alloy Compd[J], 2014, 585: 19

15 Jia Min, Zheng Ziqiao, Gong Zhu. J Alloy Compd [J], 2014, 614: 131

16 Li Hongying, Su Xiongjie, Yin Hao et al. Trans Nonferrous Met Soc China[J], 2013, 23: 2543

17 Ujihara T, Fujiwara K, Sazaki G et al. Cryst Groth[J], 2002, 241(3): 387

18 Samaras S N, Haidemenopoulos G N. Mater Process Technol[J], 2007, 194(3): 63

19 Zhang Xinming, Han Nianmei, Liu Shengdan et al. The Chinese Journal of Nonferrous Metals[J], 2010, 20(2): 202 (in Chinese) 
20 Xie F Y, Yan X Y, Ding L et al. Materials Science and Engineering $A[\mathrm{~J}], 2003,355: 144$

21 Zhang Fei, Shen Jian, Yan Xiaodong et al. Rare Metals[J], 2014, 33(2): 28
22 Deng Ying, Yin Zhimin, Cong Fuguan. Intermetallics[J], 2012, 26: 114

23 Rokhlin L L, Dobatkina T V, Bochvar N R et al. J Alloy Compd [J], 2004, 367(2): 10

\title{
Al-Cu-Li 合金均匀化处理参数优化和微观组织演化
}

\author{
杨胜利 ${ }^{1,2}$, 沈 健 ${ }^{1,2}$, 间晓东 ${ }^{2}$, 李锡武 ${ }^{1}$, 张 飞 ${ }^{2}$, 孙宝庆 ${ }^{2}$
}

(1. 北京有色金属研究总院 有色金属材料制备加工国家重点实验室, 北京 100088)

(2. 北京有色金属研究总院 有色金属加工事业部，北京 100088)

\begin{abstract}
摘 要: 对 Al-Cu-Li 铸态合金进行单级和双级均匀化处理, 通过光学显微镜 (OM)、扫描电镜 (SEM)、能谱分析 (EDS)、 X 衍射 (XRD) 和差热分析 (DSC) 研究合金元素分布和微观组织演化。结果表明: $\mathrm{Al}-\mathrm{Cu}-\mathrm{Li}$ 合金铸态组织存在严重枝晶偏析, 由晶内到晶界 Cu 元素 分布十分不均匀, $\mathrm{Mg} 、 \mathrm{Zn} 、 \mathrm{Mn}$ 和 $\mathrm{Ag}$ 变化不明显。晶界处存在大量的非平衡共晶相, 主要包括 $\mathrm{Al}_{2} \mathrm{Cu}$ 、含有少量 $\mathrm{Mg}_{\mathrm{c}}$ 素的 $\mathrm{Al}_{2} \mathrm{Cu}$ 相, 以及 $\mathrm{Al}_{2} \mathrm{CuMg}$ 相。经双级均匀化 $\left(495^{\circ} \mathrm{C} / 24 \mathrm{~h}+515^{\circ} \mathrm{C} / 24 \mathrm{~h}\right)$ 处理后, 大部分非平衡共晶相和部分第二相 $\left(\mathrm{Al}_{2} \mathrm{CuMg}\right.$ 和 $\left.\mathrm{Al}{ }_{2} \mathrm{CuLi}\right)$ 溶解到合 金基体，但仍有部分富- $\mathrm{Fe}$ 和富- $\mathrm{Mn}$ 相残留在晶界不能回溶。 $\mathrm{Al}_{2} \mathrm{CuMg}$ 相的熔点低于 $\mathrm{Al}_{2} \mathrm{Cu}$ 相，两者分别在 495 和 $515^{\circ} \mathrm{C}$ 先后溶解。通过均 匀化动力学分析, 确定 $\mathrm{Al}-\mathrm{Cu}-\mathrm{Li}$ 铝锂合金最佳的均匀化制度为 $495{ }^{\circ} \mathrm{C} / 24 \mathrm{~h}+515^{\circ} \mathrm{C} / 24 \mathrm{~h}$, 该双级均匀化制度与动力学分析结果一致。
\end{abstract} 关键词: $\mathrm{Al}-\mathrm{Cu}-\mathrm{Li}$ 合金; 均匀化处理; 非平衡共晶相; 动力学分析

作者简介: 杨胜利, 男, 1986 年生, 博士生, 北京有色金属研究总院有色金属材料制备加工国家重点实验室, 北京 100088, 电话: 010-82241172, E-mail: bravictors@126.com 